Article

\title{
Sustainable Innovation in Higher Education: The Impact of Gender on Innovation Competences
}

\author{
Raquel Ferreras-Garcia ${ }^{1, *(\mathbb{D})}$, Jordi Sales-Zaguirre ${ }^{2}$ and Enric Serradell-López ${ }^{1}$ \\ 1 School of Business and Economics, Universitat Oberta de Catalunya, 08035 Barcelona, Spain; \\ eserradell@uoc.edu \\ 2 School of Tourism and Hospitality Management Sant Ignasi, Universitat Ramon Llull, 08034 Barcelona, Spain; \\ jordi.sales@htsi.url.edu \\ * Correspondence: rferreras@uoc.edu
}

Citation: Ferreras-Garcia, R.;

Sales-Zaguirre, J.; Serradell-López, E. Sustainable Innovation in Higher Education: The Impact of Gender on Innovation Competences.

Sustainability 2021, 13, 5004. https:// doi.org/10.3390/su13095004

Academic Editor: Yuzhuo Cai

Received: 24 March 2021

Accepted: 28 April 2021

Published: 29 April 2021

Publisher's Note: MDPI stays neutral with regard to jurisdictional claims in published maps and institutional affiliations.

Copyright: (c) 2021 by the authors. Licensee MDPI, Basel, Switzerland. This article is an open access article distributed under the terms and conditions of the Creative Commons Attribution (CC BY) license (https:// creativecommons.org/licenses/by/ $4.0 /)$.

\begin{abstract}
There is currently an increasing interest for sustainable innovation in our society. The European agendas highlight the role of higher education institutions in the formation and development of innovation competences among students. Our study aimed to contribute to the analysis of the level of achievement of students' innovation competences by considering two sustainable development goals (SDG) of the 2030 United Nations' Agenda: Gender Equality (SDG 5) and Quality Education (SDG 4). This article tries to answer how business students perceive their own innovation competences and which innovative competences are best achieved by students, as well as if there are differences in the achievement of these competences depending on the students' gender. Our results, from a sample of 360 students in the Business Administration and Management Bachelor's Degree at the Universitat Oberta de Catalunya, confirm the extensive development of innovation competences. Moreover, female students present a high level of preparation for innovation-oriented action. These findings have educational implications for potentiating the innovation competences and environments where females can attain innovation skills.
\end{abstract}

Keywords: gender; innovation competences; sustainable innovation; higher education

\section{Introduction}

Every sector of the economy is keenly aware of the importance of innovation. It is considered vital to securing a competitive advantage, amongst other reasons, because it is an intangible asset that competitors have trouble replicating [1-3] and it enables companies to boost productivity [4,5], improve product quality [4], and lower production costs [6-8].

According to the Oslo Manual, innovation is any new or improved product or process that differs from previous products or processes and has been made available to users [9]. It is also linked to education and the need for workers to possess key skills; indeed, professionals involved in innovation processes must be competitive in the products and services they offer [10]. Therefore, educating future innovators necessarily means setting up strategies that foster creativity and hone the skills required to engage in innovation processes [11,12].

Meanwhile, there has been strong consensus in discussions surrounding corporate sustainability that innovation is of the utmost importance for achieving sustainability and that sustainability-related challenges harbour significant potential for innovation and the creation of new business opportunities [13]. The concept of sustainability innovation distinguishes between an innovation's private and social benefit. In this way, the greater the private benefit, the greater is the potential that an innovation has to compensate for its social drawbacks [14].

The European Commission's [15] agenda underlines the unique role of higher education institutions in providing effective and efficient innovation training. Although education plays a pivotal role in the development of innovation skills, several studies 
suggest that higher education institutions are unable to fully meet such a demand $[16,17]$. Their authors stress the need to update teaching practices and create assessment tools that can measure and develop students' capacity for innovation $[18,19]$, thereby narrowing the gap between university curricula and society's ongoing needs $[10,20]$.

Driving innovation forward to achieve more innovative societies is at the centre of the current debate on the agendas of most university institutions. Likewise, building an innovative culture largely hinges on students' development of general competences [18]. Whilst there have been very welcome changes in higher education, this does not mean that gender equality has been achieved [21]. UNESCO's World Atlas of Gender Equality in Education concludes that "It is often the case where a better level of education doesn't necessarily translate into better employment opportunities. Even though women outperform men in education, they still face significant shortfalls and discrimination in the labour market and end up in jobs where they don't use any of their skills. However, even though education is not the only input into women's empowerment it is nonetheless a central one" [22] (p. 107). So, the task of transforming higher education to make female students more equal remains a distant prospect [21].

Today's society needs innovative professionals, spurring educational institutions to seek out ways to foster innovation competences among their students and thus meet social demands $[12,23,24]$. Behind all business innovation lies people's capacity to innovate, making innovation competences the lifeblood of companies and organisations alike. Accordingly, the ultimate aim must be to train future professionals to be instrumental in creating new innovations. Previous literature has shown that students need to have acquired specific innovation-related skills during their studies in order for this to happen [25-27], noting that educators have made great efforts to stimulate innovation competences through teaching [11].

Scientific literature has put forth multiple definitions of the term "competence". According to the European Qualifications Framework for Lifelong Learning [28], it may be understood as "the proven ability to use knowledge, skills and personal, social and/or methodological abilities, in work or study situations and in professional and personal development". Edwards-Schacter et al. [18] highlight that all competences can be learned and taught as part of the personal development process embedded in educational environments. Competence-building is a dynamic undertaking requiring time and taking place over the course of one's entire education.

Several authors have defined innovation competence. West and Farr [29] understand it as "the capacity to generate original, appropriate and implementable solutions to problems", whilst Tidd and Bessant [30] define it as "the capacity to develop creative ideas that can be implemented successfully as products, services, procedures, theories and strategies that are useful or meaningful to the intended audience".

The ability to innovate is considered central in many higher education settings and is identified as a fundamental learning outcome and a core competence for professional success. In order for people to engage in innovative activities in the workplace, they need to have developed a set of specific skills and competences over the course of their education $[19,27,31]$, and these skills are more keenly honed when they are embedded in curricula as a focus of the learning process [32,33].

The literature has analysed academically the components of innovation competence that ought to be developed, reaching descriptions that vary considerably. Some of the competences that particularly stand out in innovative individuals are those related to high-level creative and leadership abilities, energy, persistence, task motivation, creative self-efficacy, the propensity to take calculated risks, and enthusiasm towards working on ambiguous and complex problems $[34,35]$. Other authors have followed the three-dimension model, which focuses specifically on innovation competences [16,36-39]. In this model, innovation competences are structured around three dimensions or scales: individual, interpersonal, and networking. The individual dimension identifies a person's abilities with respect to an organisation's innovation processes. These skills are linked to creativity, idea generation, 
initiative, goal-oriented actions, decision-making, critical thinking, problem-solving, perseverance, risk-taking, and one's personal attitude. The interpersonal dimension is based on communication, teamwork, and team leadership. Finally, the networking dimension covers the ability to create and maintain work relationships, work in networks, cooperate in multidisciplinary and multicultural environments, and communicate and interact in international settings. Other studies have been based on the three-dimension model and have restructured it, proposing a classification of innovation competences in five dimensions that describes the behaviour or actions required to carry out innovative processes: creativity, critical thinking, teamwork, initiative, and networking [10,40,41].

Different studies have analysed how to measure innovation competences, providing, for example, a questionnaire that enables organisations to identify these competences in their employees [2]. Other research has focused on the development of innovation competences [42,43], devised tools for measuring higher education students' innovativeness [36,43-45], or proposed competence models based on innovation in pedagogical contexts [46-48].

Other studies have explored how learning environments influence the achievement of innovation competences. Innovation pedagogy $[10,20]$, for example, is a strategy that permeates an entire organisation and its activities and bolsters students' development of competences for engaging in innovation creation processes. The results show that the more experience students have in innovation pedagogy learning environments, the higher they score in innovation competences [10]. However, the learning environment does not always exert a relevant influence. The results presented in Ovbiagbonhia et al. [49], for instance, indicate that students, despite having positive perceptions of their achievement of innovation competences, believe that the learning environment only boosts their innovation competences development to a limited extent. These results suggest that universities may need to focus more explicitly and structurally on teaching and assessing innovation competence.

The scientific literature has also addressed the relationship between innovation and entrepreneurship, confirming the tight bond between the two. Indeed, entrepreneurship drives innovation and opportunity seeking, thus generating a positive impact on countries' wealth, social growth, and sustainable business development [50-52]. In turn, Portuguez et al. [53] recognise the valuable role that higher education plays in creating synergies between innovation and entrepreneurship, while Yordanova et al. [54] remark that universities are increasingly involved in creating an internal, favourable environment supporting entrepreneurship and innovation. University entrepreneurship programmes aid students' development of creativity and innovativeness [55] and provide society with more entrepreneurs and innovators [56,57].

Another aspect that has gained interest in recent years in the academic, social, and business fields, presenting itself as a question of social sustainability, is gender [58]. The sustainable development of societies, businesses, and, ultimately, countries is affected, amongst other factors, by the powerful driving force that is gender equality [59]. That being so, gender disparity has become a pressing issue for society and sustainability, making its way onto the priority agenda of policy-makers, especially in continental Europe [60]. In 2015, the United Nations approved the 2030 Agenda for Sustainable Development [61], an opportunity for countries to embark on a new path towards improving people's lives whilst leaving no one behind. The 2030 Agenda has 17 Sustainable Development Goals (SDGs), and this paper strongly supports two of them: Gender Equality (SDG 5) and Quality Education (SDG 4). Gender differences have also been the focus of researchers in the fields of management and education.

Management literature has concentrated on the obstacles that women must overcome in the world of business, paying special attention to issues such as the gender pay gap and the glass ceiling that prevents women from reaching the top rung of the corporate ladder [62-64]. Other matters affected by gender differences have also been addressed in the academic literature. Gender difference theories argue that men engage in entrepreneurship 
more than women [65,66], owing primarily to women's risk aversion [67-69], while women display keener problem-solving skills [63,64]. In addition, women hold values [64] and possess knowledge and experience [62,70] that differ from those of their male counterparts. It should also be noted that a higher proportion of women in top management positions tend to have positive effects on firm performance [71,72].

Research has also investigated the relationship between gender and innovation, leading to conflicting results. Some studies have revealed a negative link between gender diversity and innovation, mainly based, as in the case of entrepreneurship, on the different attitudes towards risk displayed by men and women [24]. These notwithstanding, other studies have provided evidence of the positive and significant contribution of women managers in research and development (R\&D) and organisational innovation $[58,60]$.

Gender differences have also been studied in the field of higher education, where they are found to affect students' learning behaviour [73], performance [74], and learning outcomes [75]. Gender differences also influence competence achievement. For example, researchers have written extensively about the association between analytical, mathematical, and scientific skills and the male gender $[76,77]$, whilst social, communication, and organisation skills are generally associated with the female gender [76,78].

However, although the literature contains relevant studies on the topic of competences, there is insufficient empirical evidence related to gender. Additionally, to the best of our knowledge, there are no previous studies that specifically analyse students' perception of innovation competence achievement and the impact of gender on the development of such competences.

Students' innovation competence development is of growing importance in higher education. Nevertheless, existing results remain inconclusive, thus laying bare the need for more empirical evidence. This study was designed to fill this gap in the literature by analysing the innovation competence level of students on the Bachelor's Degree in Business Administration and Management at the Universitat Oberta de Catalunya (UOC) through a self-assessment questionnaire. Not only will this pursuit improve our knowledge of innovation competence achievement, it will provide insight into the role of gender in education and, more specifically, in competence-building. Such knowledge and insight can then be used to come up with solutions that demolish the barriers currently hindering competence development.

This leads us to pose the following research questions:

RQ1: How do business students perceive their own innovation competences?

RQ2: What innovation competences are best achieved by students?

RQ3: Are there any significant differences in how students perceive their innovation competences depending on their gender?

\section{Methods}

\subsection{Sample and Data Collection}

In this case study, data were collected from students in the Bachelor's Degree in Business Administration and Management at the Universitat Oberta de Catalunya (UOC), specifically those enrolled on the Final Bachelor's Degree Project course in their specialisation, entrepreneurship. This course was chosen because innovation and entrepreneurship competences are considered specific learning outcomes for students taking it. Turning to students in this course for our analysis of innovation competences is fully justified; indeed, as explained in the literature review above, previous studies have demonstrated the relationship between innovation and entrepreneurship [54,55]. Furthermore, participants who evaluate themselves have quality information about themselves [79] and the students in this sample are at the end of their studies, and their experience enables them to gauge their own innovation competencies.

A self-assessment e-questionnaire was made available to students for 21 days via a link in their virtual classroom at the end of the first and second semesters of the 2018/2019 
and 2019/2020 academic years, and a total of 360 responses were received. This is, in fact, the entire population, as the questionnaire was compulsory.

The questionnaire was designed to gather information on students' perception of their level of acquisition of the different groups of innovation competences. The students taking the questionnaire were instructed to rate their own innovation competences on a 5 -point Likert scale: $1=$ very poor, $2=$ poor, $3=$ average, $4=$ good, and $5=$ excellent. The first part of the questionnaire included several questions on sample characteristics, such as gender, age, the semester in which the student was taking the course, and the name of their final project tutor. The other parts of the questionnaire collected information on innovation competences. Following the three-dimension model for classifying innovation competences $[54,55]$, the questionnaire was split into three large blocks, each covering the innovation competences in the corresponding dimensions: individual, interpersonal, and networking. The three dimensions were divided into different items referring to the innovation competences included in them. Thus, the individual dimension (ID) contained 11 items, the interpersonal dimension (IPD) contained four items, and the networking dimension (ND) contained two items.

Table 1 displays the list of innovation competences analysed, classified according to the dimension to which they belong.

Table 1. Dimensions and innovation competences.

\begin{tabular}{cc}
\hline & Innovation Competences \\
\hline ID1 & Individual Dimension \\
ID2 & Creativity \\
ID3 & Perseverance \\
ID4 & Risk-taking \\
ID5 & Personal attitude \\
ID6 & Idea generation \\
ID7 & Change management \\
ID8 & Results orientation \\
ID9 & Decision-making \\
ID10 & Problem-solving \\
ID11 & Critical thinking \\
& Initiative \\
\hline IPD1 & Interpersonal Dimension \\
IPD2 & Leadership \\
IPD3 & Teamwork \\
IPD4 & Written communication \\
& Oral communication \\
\hline ND1 & Networking Dimension \\
ND2 & Work in networks \\
& Cooperate in multidisciplinary, multicultural, and international \\
& environments \\
\hline
\end{tabular}

\subsection{Data Analysis}

Statistical analyses were carried out using IBM SPSS Statistics version 24.

Table 2 shows the students' gender distribution: $51.1 \%$ (184) were male and $48.9 \%$ (176) were female. The students' mean age was 35.36 years and ranged between 23 and 62 years, with no notable differences between the mean age of male and female students.

Table 2. Distribution by gender.

\begin{tabular}{ccc}
\hline Gender & Frequency & Percentage \\
\hline Male & 184 & 51.1 \\
Female & 176 & 48.9 \\
\hline
\end{tabular}


A Cronbach's alpha test was conducted to analyse the degree of consistency and reliability of the measures. According to general consensus, the lower limit of acceptance for the Cronbach's alpha test is 0.70 . The value of the coefficient alpha for the innovation competences was 0.922 , which is above the minimum required value of 0.70 . Therefore, the data presented a high degree of internal consistency and the results are reliable.

Analysing the distribution of the variables, the Kolmogorov-Smirnov test led us to reject the null hypothesis at a significance level of $\alpha=0.05$ and conclude that the innovation competences variables did not follow a normal distribution.

\section{Results}

Table 3 displays the bivariate correlations of the innovation competences variables, showing that all variables are significantly correlated with one another at a level of $\alpha=0.01$. However, the correlations are sufficiently low to justify the use of separate scales.

Table 3. Bivariate correlation matrix.

\begin{tabular}{|c|c|c|c|c|c|c|c|c|c|c|c|c|c|c|c|c|c|}
\hline & ID1 & ID2 & ID3 & ID4 & ID5 & ID6 & ID7 & ID8 & ID9 & ID10 & ID11 & IPD1 & IPD2 & IPD3 & IPD4 & ND1 & ND2 \\
\hline ID1 & 1 & & & & & & & & & & & & & & & & \\
\hline ID2 & 0.208 & 1 & & & & & & & & & & & & & & & \\
\hline ID3 & 0.521 & 0.225 & 1 & & & & & & & & & & & & & & \\
\hline ID4 & 0.310 & 0.456 & 0.373 & 1 & & & & & & & & & & & & & \\
\hline ID5 & 0.545 & 0.229 & 0.327 & 0.282 & 1 & & & & & & & & & & & & \\
\hline ID6 & 0.330 & 0.459 & 0.353 & 0.417 & 0.238 & 1 & & & & & & & & & & & \\
\hline ID7 & 0.307 & 0.365 & 0.363 & 0.378 & 0.239 & 0.454 & 1 & & & & & & & & & & \\
\hline ID8 & 0.419 & 0.376 & 0.433 & 0.388 & 0.374 & 0.406 & 0.484 & 1 & & & & & & & & & \\
\hline ID9 & 0.393 & 0.422 & 0.427 & 0.459 & 0.342 & 0.555 & 0.567 & 0.557 & 1 & & & & & & & & \\
\hline ID10 & 0.478 & 0.287 & 0.397 & 0.374 & 0.375 & 0.354 & 0.466 & 0.563 & 0.474 & 1 & & & & & & & \\
\hline ID11 & 0.546 & 0.372 & 0.442 & 0.414 & 0.454 & 0.392 & 0.511 & 0.520 & 0.581 & 0.454 & 1 & & & & & & \\
\hline IPD1 & 0.365 & 0.356 & 0.317 & 0.454 & 0.367 & 0.399 & 0.370 & 0.571 & 0.504 & 0.418 & 0.442 & 1 & & & & & \\
\hline IPD2 & 0.232 & 0.348 & 0.176 & 0.398 & 0.304 & 0.412 & 0.337 & 0.409 & 0.393 & 0.390 & 0.379 & 0.437 & 1 & & & & \\
\hline IPD3 & 0.239 & 0.376 & 0.209 & 0.279 & 0.285 & 0.338 & 0.391 & 0.403 & 0.361 & 0.319 & 0.323 & 0.356 & 0.476 & 1 & & & \\
\hline IPD4 & 0.292 & 0.363 & 0.328 & 0.462 & 0.307 & 0.367 & 0.351 & 0.511 & 0.430 & 0.389 & 0.398 & 0.516 & 0.495 & 0.500 & 1 & & \\
\hline ND1 & 0.269 & 0.251 & 0.144 & 0.356 & 0.335 & 0.363 & 0.217 & 0.283 & 0.302 & 0.299 & 0.302 & 0.523 & 0.512 & 0.367 & 0.469 & 1 & \\
\hline ND2 & 0.305 & 0.325 & 0.255 & 0.262 & 0.330 & 0.343 & 0.339 & 0.396 & 0.363 & 0.373 & 0.359 & 0.486 & 0.432 & 0.304 & 0.390 & 0.409 & 1 \\
\hline
\end{tabular}

$\mathrm{N}=360$. Significance codes: $p$-value 0.01 .

Table 4 shows the means and corresponding standard deviations of the innovation competences variables. The standard deviation is low for all items. The results show that students perceive themselves as having achieved innovation competences to a high degree, with values above 4 points in most cases. Students only rated themselves below this level on two competences, specifically risk-taking (ID3) and oral communication (IPD4), although neither presents a remarkably low achievement level.

Overall, the students perceive that they have best achieved the innovation competence of perseverance (ID2), with a score notably above the rest at 4.53 . This is followed by change management (ID6), problem-solving (ID9), and initiative (ID11), with point values of $4.39,4.34$, and 4.31 , respectively. The remaining innovation competences exhibit high values as well.

Personal attitude (ID4) and results orientation (ID7) earned respective point values of 4.29 and 4.28; idea generation (ID5), leadership (IPD1), teamwork (IPD2), decision-making (ID8), written communication (IPD3), and critical thinking (ID10) came in with scores between 4.15 and 4.20; the two networking dimension competences-the ability to work in networks (ND1) and the ability to cooperate in multidisciplinary, multicultural, and international environments (ND2) - were scored at 4.08 and 4.02, respectively; and, finally, creativity (ID1) landed at 4 points, followed by oral communication (IPD4) at 3.94 points, and risk-taking (ID3) at 3.65 points. Worthy of note is how much the individual innovation competences stand out, accounting for the students' top seven most highly rated items. 
Table 4. Descriptive statistics of innovation competences.

\begin{tabular}{cccccc}
\hline Innovation Competences & $\boldsymbol{n}$ & Min. $^{\mathbf{1}}$ & Max. $^{\mathbf{2}}$ & Mean & S.D. $^{{ }^{3}}$ \\
\hline ID1 & 360 & 2 & 5 & 4.00 & 0.774 \\
ID2 & 360 & 2 & 5 & 4.53 & 0.615 \\
ID3 & 360 & 1 & 5 & 3.65 & 0.834 \\
ID4 & 360 & 1 & 5 & 4.29 & 0.746 \\
ID5 & 360 & 2 & 5 & 4.20 & 0.682 \\
ID6 & 360 & 2 & 5 & 4.39 & 0.637 \\
ID7 & 360 & 2 & 5 & 4.28 & 0.672 \\
ID8 & 360 & 2 & 5 & 4.18 & 0.672 \\
ID9 & 360 & 2 & 5 & 4.34 & 0.608 \\
ID10 & 360 & 2 & 5 & 4.15 & 0.709 \\
ID11 & 360 & 2 & 5 & 4.31 & 0.668 \\
IPD1 & 360 & 2 & 5 & 4.19 & 0.721 \\
IPD2 & 360 & 2 & 5 & 4.19 & 0.640 \\
IPD3 & 360 & 2 & 5 & 4.16 & 0.740 \\
IPD4 & 360 & 1 & 5 & 3.94 & 0.800 \\
ND1 & 360 & 1 & 5 & 4.02 & 0.790 \\
ND2 & 360 & 2 & 5 & 4.08 & 0.721 \\
\hline
\end{tabular}

${ }^{1}$ Min. Minimum value. ${ }^{2}$ Max. Maximum value. ${ }^{3}$ S.D. Standard deviation.

In sum, students perceive that they have achieved the innovation competences well, likely due to the fact that their degree programme fosters the development of these competences in all courses.

Segmenting the sample by gender, the results (Table 5) point to greater innovation competence achievement among female students, holding true for 12 of the 17 competences. It should be noted that women perceive their achievement to be greater in all the innovation competences in the interpersonal and networking dimensions. Meanwhile, achievement perception is more evenly distributed in the individual dimension, where men perceive greater achievement in five competences and women in the remaining six.

Table 5. Means of innovation competences for the gender variable.

\begin{tabular}{cccccccccc}
\hline Gender & ID1 & ID2 & ID3 & ID4 & ID5 & ID6 & ID7 & ID8 & ID9 \\
\hline Male & 4.00 & 4.46 & 3.67 & 4.32 & 4.16 & 4.32 & 4.29 & 4.15 & 4.30 \\
Female & 3.99 & 4.60 & 3.63 & 4.26 & 4.23 & 4.47 & 4.26 & 4.20 & 4.38 \\
\hline Gender & ID10 & ID11 & IPD1 & IPD2 & IPD3 & IPD4 & ND1 & ND2 & \\
\hline Male & 4.16 & 4.24 & 4.14 & 4.05 & 4.07 & 3.91 & 3.91 & 3.98 & \\
Female & 4.14 & 4.38 & 4.24 & 4.34 & 4.26 & 3.98 & 4.13 & 4.18 & \\
\hline
\end{tabular}

Along these same lines, the results show that perseverance (ID2) is rated the highest by both female and male students, with respective point values of 4.6 and 4.46 . This is followed by change management (ID6) in both cases, for which the point values are 4.47 and 4.32, respectively. Moreover, women averaged higher in the four best-achieved competences: perseverance (ID2), change management (ID6), problem-solving (ID9), and initiative (ID11).

Differences were tested using the non-parametric Mann-Whitney U test (Table 6). The results show that at a significance level of $\alpha=0.05$, perseverance (ID2), teamwork (IPD2), written communication (IPD3), the ability to work in networks (ND1), and the ability to cooperate in multidisciplinary, multicultural, and international environments (ND2) present significant mean differences when compared by gender. At a significance level of $\alpha=0.1$, change management (ID6) and initiative (ID11) also display significant differences. For all the competences with significant differences, women's perceived level of competence achievement is higher than that of men's. Therefore, it can be said that the women in our sample are better prepared for innovation-oriented action. 
Table 6. Statistical tests of the innovation competences for the gender variable.

\begin{tabular}{cccccccccc}
\hline & ID1 & ID2 & ID3 & ID4 & ID5 & ID6 & ID7 & ID8 & ID9 \\
\hline Mann-Whitney U test & 15,875 & 14,457 & 15,484 & $15,342.5$ & 15,597 & $14,574.5$ & 15,666 & 15,443 & 15,494 \\
Wilcoxon W test & 31,451 & 31,477 & 31,060 & $30,918.5$ & 32,617 & $31,594.5$ & 31,242 & 32,463 & 32,514 \\
$Z$ & -0.346 & -2.027 & -0.767 & -0.940 & -0.667 & -1.832 & -0.587 & -0.846 & -0.797 \\
$\begin{array}{c}\text { Asymptotic significance } \\
\text { (2-sided) }\end{array}$ & 0.730 & $0.043 * *$ & 0.443 & 0.347 & 0.504 & $0.067 *$ & 0.557 & 0.397 & 0.425 \\
\hline & ID10 & ID11 & IPD1 & IPD2 & IPD3 & IPD4 & ND1 & ND2 \\
\hline $\begin{array}{c}\text { Mann-Whitney U test } \\
\text { Wilcoxon W test }\end{array}$ & $15,732.5$ & 14,672 & 15,148 & 12,575 & 13,996 & 15,551 & 13,834 & 14,011 \\
$\begin{array}{c}\text { Z } \\
\text { Asymptotic significance } \\
\text { (2-sided) }\end{array}$ & -0.513 & -1.699 & -1.160 & -4.146 & -2.416 & -0.703 & -2.582 & -2.447 \\
\hline
\end{tabular}

Significance codes: ${ }^{* *} p$-value $0.05,{ }^{*} p$-value 0.1 .

\section{Discussion}

The economic, business, and social impact of innovation has received much attention from the scientific community in what is known as innovation research. Innovation is driven by people with the right competences, and it is here that higher education represents a critical factor in the development of human capital $[18,25,27]$. The role of higher education institutions is not only to educate university students for the world of work, but also to go a step further and train future professionals to perform work tasks that generate innovations and meet the needs of today's society [18].

In this regard, higher education is the bedrock of strong, well-developed innovation competences. Although there have been studies on aspects related to innovation competences in the university sphere, further research is necessary to better understand the achievement of this type of competence. This paper aims to further previous research by providing empirical evidence on the development of innovation competences.

The results of our research show that students have positive perceptions of their innovation competence achievement, making it clear that their university studies have fostered their development. These results are in line with previous research, where for most competences students' responses give a mean score in the medium-high range [10,45,49].

In our sample, students perceived that they were most proficient in the innovation competences of perseverance, change management, problem-solving, and initiative, with most of the individual competences showing the highest levels of achievement. These results partially match those of previous studies, where the competences perceived to be best achieved were energy, creativity, creative self-efficacy, and teamwork, whilst the ability to solve ambiguous problems, risk-taking, communication, networking, and leadership scored lower $[45,49]$.

According to Chell and Athayde [80], higher scores on innovative competences are likely to represent students' intentions to become future innovators, whilst lower scores on risk propensity may indicate a lack of teaching of risk control mechanisms or may be explained by students' socioeconomic background. The students in our sample freely chose to undertake their final bachelor's degree project in the area of entrepreneurship. Thus, the close relationship between entrepreneurship and innovation found in previous literature $[53,55]$ could partially explain their high competence achievement. The learning environment could also provide a possible explanation, as suggested by Keinänen and Kairisto-Mertanen [10], who found that students with previous study experiences in innovative learning environments report higher levels of innovation competences. The fact that the students in our sample have previously taken courses such as Entrepreneurial Initiative, Innovation Management, and Change Management, in which innovation competence development is a learning outcome in and of itself, would imply that they have received good innovation training during their degree, which could in turn help to explain 
their high achievement of innovation competences. In any case, further research would be necessary to find out whether these factors truly boost innovativeness.

Sustainable innovation, where gender takes on special relevance as a social justice issue and a crucial ingredient for sustainability, is another key factor that needs to be addressed [58]. Indeed, the scientific community has evinced a growing interest in embracing gender as an element of analysis and quality for the achievement of sustainable innovation. Aiming to contribute to sustainable innovation research, our study used gender as a variable to shed light on possible gender-based differences in innovation competence achievement amongst students.

The results show that female students achieve innovation competences better than their male counterparts overall, especially in the interpersonal and networking dimensions. Male and female students exhibit significant differences in several specific competences, with the latter perceiving greater achievement than the former in most cases. These are perseverance, change management, initiative, teamwork, written communication, the ability to work in networks, and the ability to cooperate in multidisciplinary, multicultural, and international environments. Thus, the results demonstrate the positive influence of gender on the development of innovation competences, with women being better prepared for innovative environments.

Our results partially confirm those of previous studies. For example, female students display more risk aversion than their male counterparts [67-69], yet they exhibit better problem-solving skills $[62,63]$, decision-making, creativity, communication, and networking $[58,60,76,78]$, which are conducive to innovation.

Unfortunately, very few studies have explored the relationship between gender and the achievement of innovation competences in the scope of higher education, thus limiting our ability to compare our results with those of previous research. The only study we have found that takes into account the gender variable is Keinänen and Oksanen [41]; according to the results of the self-assessment questionnaire they administered to a small sample of engineering students $(n=77)$, gender was not statistically associated with the learning outcomes of innovation competences. This clashes with the results of our study.

These contradictory results are an opportunity to further pursue this important research line on the relationship between innovation and gender. In order to better respond to labour needs, train innovative graduates, and develop effective learning environments for innovation-oriented action, more research is needed on how students develop innovation competences, taking into account different factors that may affect their development, such as gender. Finally, we believe that this study, thanks to its gender perspective, sheds light on the relationship between higher education and the achievement of innovation competences, thus making decisive progress on the roadmap of the United Nations' SDGs.

Despite the various contributions of this paper, the study has some limitations. First, focusing on a single course on a single degree programme leads to limitations with respect to the possibility of extrapolating our results. Second, there is a risk of possible bias in the self-assessments given that people often rate themselves favourably. However, previous studies have shown that such assessments are nonetheless valid because people possess better quality information about themselves [79], and expert assessments also present contradictions [81]. Knowing to what extent they have actually achieved innovation competences would allow students to monitor and regulate their own learning by reflecting on whether they have met or exceeded the standards of their programme [82] and prepare them for a more complex work environment [16]. Third, this study has limited itself to exploring a set of factors that may influence innovation competence development. However, as shown in other studies, innovation competences can be affected by other variables such as personality, environment, and the professor's teaching style. These limitations convey that the present study is only a first step and that further studies are needed to measure innovation competences and the influence of different factors at other educational stages. 
Indeed, future research could help to fill these gaps. We would advise extending the sample to include students from other courses, degrees, or universities to overcome the limitation of analysing a potentially non-representative study population. The sample could even be extended to include students that are not linked to any entrepreneurial project. It would also be interesting to compare students' perceptions of their achievement of innovation competences and their actual achievement, as measured by teaching staff through rubric-based assessment; this is a research line we are currently pursuing. Another valid pursuit would be to study a population other than university students, to find out whether high achievement of innovation competences is due to university students having a greater capacity for innovation than other people. Finally, a study could be carried out to assess whether these students are successful in their innovative endeavours once they enter the world of work or launch a business.

Despite the study's limitations, the results are encouraging and further our knowledge of this subject. Students' high achievement of innovation competences supports the validity of the educational system in terms of its pedagogical efficacy in helping to hone students' innovativeness and meeting the innovation demands of society.

\section{Conclusions}

The complex nature of sustainability innovation and its multiple components has led to a lack of conclusive academic results. This study, one of the first of its kind, contributes to innovation and gender research by providing a valid and reliable analysis of innovation competence development in business administration and management students. Moreover, it validates that gender is a key factor of innovation competence development and should thus be taken into consideration.

The results of this study make a valuable contribution to the academic community, as they provide insight into students' achievement of innovation competences. The existing gap in the literature has been taken into account to improve the comprehension of the role of gender in innovation competences. The analysis reveals which competences are better achieved and which need to be reviewed so that students can further hone them. Meanwhile, the gender perspective provides a reference so that training protocols can be applied to diminish the bias between male and female students.

The results further our knowledge of innovation competence development in the university sphere and may be useful when defining and designing new curricula whose aim is to turn out future innovators. Teaching staff may also use our results to analyse their students' achievement levels and decide whether they should take measures to improve them.

Author Contributions: Conceptualization, R.F.-G. and E.S.-L.; methodology, R.F.-G. and E.S.-L.; formal analysis, R.F.-G. and J.S.-Z.; data curation, J.S.-Z.; writing-original draft preparation, R.F.-G.; writing-review and editing, J.S.-Z. and E.S.-L.; funding acquisition, J.S.-Z. All authors have read and agreed to the published version of the manuscript.

Funding: This research was funded by Fundació La Caixa. The APC was funded by Fundació La Caixa.

Institutional Review Board Statement: Not applicable.

Informed Consent Statement: Not applicable.

Data Availability Statement: Data sharing not applicable.

Conflicts of Interest: The authors declare no conflict of interest.

\section{References}

1. Bessant, J.; Caffyn, S.; Gallagher, M. An evolutionary model of continuous improvement behaviour. Technovation 2001, $21,67-77$. [CrossRef]

2. Cerinšek, G.; Dolinsek, S. Identifying employees' innovation competency in organisations. Int. J. Innov. Learn. 2009, 6, 164-177. [CrossRef] 
3. Klippel, A.F.; Petter, C.O.; Antunes, J. Management Innovation, a way for mining companies to survive in a globalized world. Util. Policy 2008, 16, 332-333. [CrossRef]

4. Grütter, A.W.; Field, J.M.; Faull, N.H.B. Work team performance over time: Three case studies of South African manufacturers. J. Oper. Manag. 2002, 20, 641-657. [CrossRef]

5. Rapp, C.; Eklund, J. Sustainable development of improvement activities: The long-term operation of a suggestion scheme in a Swedish company. Total Qual. Manag. 2002, 13, 945-969. [CrossRef]

6. Bond, T.C. The role of performance measurement in continuous improvement. Meas. Bus. Excell. 2002, 6, 52. [CrossRef]

7. Modarress, B.; Ansari, A.; Lockwood, D.L. Kaizen costing for lean manufacturing: A case study. Int. J. Prod. Res. 2005, 43, 1751-1760. [CrossRef]

8. Terziovski, M.; Sohal, A.S. The adoption of continuous improvement and innovation strategies in Australian manufacturing firms. Technovation 2000, 20, 539-550. [CrossRef]

9. OECD/Eurostat. Oslo Manual 2018: Guidelines for Collecting, Reporting and Using Data on Innovation. In The Measurement of Scientific, Technological and Innovation Activities, 4th ed.; OECD Publishing: Paris, France, 2018. [CrossRef]

10. Keinänen, M.; Kairisto-Mertanen, L. Researching learning environments and students' innovation competences. Educ. Train. 2019, 61, 17-30. [CrossRef]

11. Beghetto, R.A.; Kaufman, J.C. Classroom contexts for creativity. High Abil. Stud. 2014, 25, 53-69. [CrossRef]

12. Richardson, C.; Mishra, P. Learning environments that support student creativity: Developing the SCALE. Think. Skills Creat. 2018, 27, 45-54. [CrossRef]

13. Hansen, E.G.; Grosse-Dunker, F.; Reichwald, R. Sustainability innovation cube-a framework to evaluate sustainability-oriented innovations. Int. J. Innov. Manag. 2009, 13, 683-713. [CrossRef]

14. Schaltegger, S.; Wagner, M. Sustainable entrepreneurship and sustainability innovation: Categories and interactions. Bus. Strategy Environ. 2011, 20, 222-237. [CrossRef]

15. European Commission. Communication from the Commission to the European Parliament, the Council. The European Economic and Social Committee and the Committee of the Regions on a Renewed EU Agenda for Higher Education. 2017. Available online: https:/ / eur-lex.europa.eu/legal-content/ES/TXT/PDF/?uri=CELEX:52017DC0247\&from=EN (accessed on 16 March 2021).

16. Keinänen, M.; Ursin, J.; Nissinen, K. How to measure students' innovation competences in higher education: Evaluation of an assessment tool in authentic learning environments. Stud. Educ. Eval. 2018, 58, 30-36. [CrossRef]

17. Badcock, P.; Pattison, P.; Harris, K. Developing generic skills through university study: A study of arts, science and engineering in Australia. High. Educ. 2010, 60, 441-458. [CrossRef]

18. Edwards-Schacter, M.; García-Granero, A.; Sánchez-Barrioluengo, M.; Quesada-Pineda, H.; Amara, N. Disentangling competences: Interrelationships on creativity, innovation and entrepreneurship. Think. Skills Creat. 2015, 16, 27-39. [CrossRef]

19. Kivunja, C. Innovative pedagogies in higher education to become effective teachers of 21st century skills: Unpacking the learning and innovation skills domain of the new learning paradigm. Int. J. High. Educ. 2014, 3, 37-48. [CrossRef]

20. Penttilä, T. Developing educational organizations with innovation pedagogy. Int. E J. Adv. Educ. 2016, 2, 259-267. [CrossRef]

21. David, M.E. Women and gender equality in higher education? Educ. Sci. 2015, 5, 10-25. [CrossRef]

22. UNESCO. World Atlas on Gender Equality in Education. 2012. Available online: http://www.unesco.org/new/en/mediaservices/single-view/news/unesco_launches_world_atlas_of_gender_equality_in_education/(accessed on 16 April 2021).

23. Robinson, K. Out of Our Minds; Capstone Publishing: West Sussex, UK, 2011.

24. Beghetto, R. Creativity in the classroom. In The Cambridge Handbook of Creativity; Kaufman, J.C., Sternberg, R.J., Eds.; Cambridge University Press: New York, NY, USA, 2010; pp. 447-459.

25. Avvisati, F.; Jacotin, G.; Vincent-Lancrin, S. Educating higher education students for innovative economies: What international data tell us. Tuning J. High. Educ. 2013, 1, 223-240. [CrossRef]

26. Bjornali, E.; Støren, L. Examining competence factors that encourage innovative behaviour by European higher education graduate professionals. J. Small Bus. Enterp. Dev. 2012, 19, 402-423. [CrossRef]

27. Vila, L.; Perez, P.; Morillas, F. Higher education and the development of competencies for innovation in the workplace. Manag. Decis. 2012, 50, 1634-1648. [CrossRef]

28. European Parliament Council. Recommendation of the European Parliament and of the Council of 23 April 2008 on the Establishment of the European Qualifications Framework for Lifelong Learning. Official Journal of the European Union, C 111. Available online: Eur-lex.europa.eu/legal-content/EN/TXT/PDF/?uri=CELEX:32008H0506(01)\&from=EN (accessed on 16 March 2021).

29. West, M.A.; Farr, J.L. Innovation at work. In Innovation and Creativity at Work: Psychological and Organizational Strategies; West, M.A., Farr, J.L., Eds.; John Wiley \& Sons: Chichester, UK, 1990.

30. Tidd, J.; Bessant, J. Managing Innovation, 4th ed.; John Wiley \& Sons: Chichester, UK, 2009.

31. Quintana, C.D.D.; Mora, J.; Pérez, P.J.; Vila, L.E. Enhancing the development of competencies: The role of UBC. Eur. J. Educ. 2016, 51, 10-24. [CrossRef]

32. Bath, D.; Smith, C.; Stein, S.; Swann, R. Beyond mapping and embedding graduate attributes: Bringing together quality assurance and action learning to create a validated and living curriculum. High. Educ. Res. Dev. 2004, 23, 313-328. [CrossRef]

33. Hu, C.; Horng, J.S.; Teng, C.C. Developing a model for an innovative culinary competency curriculum and examining its effects on students' performance. J. Creat. Behav. 2016, 50, 193-202. [CrossRef] 
34. Dyer, J.H.; Gregersen, H.B.; Christensen, C.M. The innovator's DNA. Harv. Bus. Rev. 2009, 87, 61-67.

35. Tierney, P.; Farmer, S.M. Creative self-efficacy development and creative performance over time. J. Appl. Psychol. 2011, 96, $277-293$. [CrossRef]

36. Hooge, F.W.; Marin-Garcia, J.A.; Carbonell, A.G.; Mas, L.E.A. Validation of a rubric to assess innovation competence. WPOM 2012, 3, 61-70.

37. Kairisto-Mertanen, L.; Penttilä, T.; Nuotio, J. Defining innovation competence-the learning outcomes of innovation pedagogy. Innov. Competence Manag. 2011, 83, 25-33.

38. Kettunen, J.; Kairisto-Mertanen, L.; Penttilä, T. Innovation pedagogy and desired learning outcomes in higher education. Horizon 2013, 21, 333-342. [CrossRef]

39. Marin-Garcia, J.A.; Andreu-Andrés, M.Á.; Atares-Huerta, L.; Aznar-Mas, L.E.; Garcia-Carbonell, A.; González-Ladrón-deGuevara, F.; Montero Fleta, B.; Perez-Peñalver, M.J.; Watts, F. Proposal of a framework for innovation competencies development and assessment (FINCODA). WPOM-Work. Pap. Oper. Manag. 2016, 7, 119-126. [CrossRef]

40. Butter, R.; van Beest, W. Psychometric Validation of a Tool for Innovation Competencies Development and Assessment. Available online: www.fincoda.eu/fincoda-blog/2017/3/27/psychometric-validation-of-a-tool-for-innovation-competenciesdevelopment (accessed on 16 March 2021).

41. Keinänen, M.; Oksanen, A. Students' perception of learning innovation competences in activity-based learning environment. Amm. Aikakauskirja 2017, 19, 48-61.

42. Berdrow, I.; Evers, F.T. Bases of competence: An instrument for self and institutional assessment. Assess. Eval. High. Educ. 2010, 35, 419-434. [CrossRef]

43. Drejer, A. How can we define and understand competencies and their development? Technovation 2001, 21, 135-146. [CrossRef]

44. Pérez-Peñalver, M.J.; Aznar-Mas, L.E.; Montero Fleta, B. Identification and classification of behavioural indicators to assess innovation competence. J. Ind. Eng. Manag. 2018, 11, 87-115. [CrossRef]

45. Marín-García, J.A.; Pérez-Peñalver, M.J.; Watts, F. How to assess innovation competence in services: The case of university students. Dir. Organ. 2013, 50, 48-62.

46. Chang, Y.; Eklund, T.; Kantola, J.I.; Vanharanta, H. International creative tension study of university students in South Korea and Finland. Hum. Factors Ergon. Manuf. Serv. Ind. 2009, 19, 528-543. [CrossRef]

47. Bikfalvi, A.; Jussila, J.; Suominen, A.; Kantola, J.; Vanharanta, H. How to boost innovation culture and innovators? In Handbook of Business and Information Management Systems; Gunasekaran, A., Sanduh, M., Eds.; World Scientific Publishing Co. Pte. Ltd.: Hackensack, NJ, USA, 2010; pp. 359-381.

48. Achcaoucaou, F.; Guitart-Tarrés, L.; Miravitlles-Matamoros, P.; Núñez-Carballosa, A.; Bernardo, M.; Bikfalvi, A. Competence assessment in higher education: A dynamic approach. Hum. Factors Ergon. Manuf. Serv. Ind. 2012, 24, 454-467. [CrossRef]

49. Ovbiagbonhia, A.R.; Kollöffel, B.; den Brok, P. Educating for innovation: Students' perceptions of the learning environment and of their own innovation competence. Learn. Environ. Res. 2019, 22, 387-407. [CrossRef]

50. Crossan, M.M.; Apaydin, M. A multi-dimensional framework of organizational innovation: A systematic review of the literature. J. Manag. Stud. 2010, 47, 1154-1191. [CrossRef]

51. O'Connor, A. A conceptual framework for entrepreneurship education policy: Meeting government and economic purpose. J. Bus. Ventur. 2013, 28, 546-563. [CrossRef]

52. Urbano, D.; Alvarez, C. Institutional dimensions and entrepreneurial activity: An international study. Small Bus. Econ. 2014, 42, 703-716. [CrossRef]

53. Portuguez Castro, M.; Ross Scheede, C.; Gómez Zermeño, M.G. The impact of higher education on entrepreneurship and the innovation ecosystem: A case study in Mexico. Sustainability 2019, 11, 5597. [CrossRef]

54. Yordanova, D.; Filipe, J.A.; Pacheco Coelho, M. Technopreneurial Intentions among Bulgarian STEM Students: The Role of University. Sustainability 2020, 12, 6455. [CrossRef]

55. Saji, B.S.; Nair, A.R. Effectiveness of innovation and entrepreneurship education in UAE higher education. Acad. Strateg. Manag. J. 2018, 17, 1-12.

56. Maritz, A.; Donovan, J. Entrepreneurship and innovation. Educ. Train. 2015, 57, 74-87. [CrossRef]

57. Donovan, J.; Maritz, P.A.; McLellan, A. Innovation training within the Australian advanced manufacturing industry. J. Vocat. Educ. Train. 2013, 65, 256-276. [CrossRef]

58. Hernández-Lara, A.B.; Gonzales-Bustos, J.P.; Alarcón-Alarcón, A. Social Sustainability on Corporate Boards: The Effects of Female Family Members on R\&D. Sustainability 2021, 13, 1982.

59. Vinokurova, N. Sustainable entrepreneurship and women in science and education: Gender equality, gender inequality. Entrep. Sustain. Issues 2015, 2, 220. [CrossRef]

60. Torchia, M.; Calabro, A.; Gabaldon, P.; Kanadli, S.B. Women directors contribution to organizational innovation: A behavioral approach. Scand. J. Manag. 2018, 34, 215-224. [CrossRef]

61. Sustainable Development Goals (United Nations). Available online: www.un.org/sustainabledevelopment/gender-equality/ (accessed on 16 March 2021).

62. Bilimoria, D.; Wheeler, J.V. Women corporate directors: Current research and future directions. In Women in Management: Current Research Issues; Davidsson, M., Burke, R.J., Eds.; Paul Chapham: London, UK, 2000; pp. 138-163.

63. Eagly, A.H. Achieving relational authenticity in leadership: Does gender matter? Leadersh. Q. 2005, 16, 459-474. [CrossRef] 
64. Singh, V.; Terjesen, S.; Vinnicombe, S. Newly appointed directors in the boardroom: How do women and men differ? Eur. Manag. J. 2008, 26, 48-58. [CrossRef]

65. Komulainen, K.; Korhonen, M.; Räty, H. Risk-taking Abilities for Everyone? Finnish Entrepreneurship Education and the Enterprising Selves Imagined by Pupils. Gend. Educ. 2009, 21, 631-649. [CrossRef]

66. Langowitz, S.; Nan, S.; Minniti, M.; Arenius, P. Global Entrepreneurship Monitor: 2004 Report on Women and Entrepreneurship. University of Illinois at Urbana-Champaign's Academy for Entrepreneurial Leadership Historical Research Reference in Entrepreneurship. 2005. Available online: https://papers.ssrn.com/sol3/papers.cfm?abstract_id=1509263 (accessed on 16 March 2021).

67. Croson, R.; Gneezy, U. Gender Differences in Preferences. J. Econ. Lit. 2009, 47, 448-474. [CrossRef]

68. Nielsen, S.; Huse, M. Women Directors' Contribution to Board Decision-Making and Strategic Involvement: The Role of Equality Perception. Eur. Manag. Rev. 2010, 7, 16-29. [CrossRef]

69. Villasana, M.; Alcaraz-Rodríguez, R.; Álvarez, M.M. Examining Entrepreneurial Attributes of Latin American Female University Students. Gend. Educ. 2016, 28, 148-166. [CrossRef]

70. Hillman, A.J. Board diversity: Beginning to unpeel the onion. Corp. Gov. Int. Rev. 2015, 23, 104-107. [CrossRef]

71. Martín-Ugedo, J.F.; Minguez-Vera, A. Firm Performance and Women on the Board: Evidence from Spanish Small and MediumSized Enterprises. Fem. Econ. 2014, 20, 136-162. [CrossRef]

72. Smith, N.; Smith, V.; Verner, M. Do women in top management affect firm performance? A panel study of 2500 Danish firms. Int. J. Prod. Perform. Manag. 2006, 55, 569-593. [CrossRef]

73. Vecchione, M.; Alessandri, G.; Marsicano, G. Academic Motivation Predicts Educational Attainment: Does Gender Make a Difference? Learn. Individ. Differ. 2014, 32, 124-131. [CrossRef]

74. Chen, S.C.; Yang, S.J.; Hsiao, C.C. Exploring Student Perceptions, Learning Outcome and Gender Differences in a Flipped Mathematics Course. Br. J. Educ. Technol. 2016, 47, 1096-1112. [CrossRef]

75. Ferreras-Garcia, R.; Hernández-Lara, A.B.; Serradell-López, E. Gender and learning results: A study on their relationship in entrepreneurship education and business plans. Stud. High. Educ. 2020, 1-16. [CrossRef]

76. Due, K. Who is the Competent Physics Student? A Study of Students' Positions and Social Interaction in Small-Group Discussions. Cult. Stud. Sci. Educ. 2014, 9, 441-459. [CrossRef]

77. Gonsalves, A.J.; Danielsson, A.; Pettersson, H. Masculinities and Experimental Practices in Physics: The View From Three Case Studies. Phys. Rev. Phys. Educ. Res. 2016, 12, 020120. [CrossRef]

78. Archer, L.; Pratt, S.D.; Phillips, D. Working-class Men's Constructions of Masculinity and Negotiations of (Non)Participation in Higher Education. Gend. Educ. 2001, 13, 431-449. [CrossRef]

79. Harris, F.; Harper, S.R. Masculinities Go to Community College: Understanding Male Identity Socialization and Gender Role Conflict. New Dir. Community Coll. 2008, 142, 25-35. [CrossRef]

80. Chell, E.; Athayde, R. The Identification and Measurement of Innovative Characteristics of Young People; NESTA: London, UK, 2009.

81. Paulhus, D.L.; Vazire, S. The self-report method. In Handbook of Research Methods in Personality Psychology; Robins, R.W., Fraley, R.C., Krueger, R.F., Eds.; The Guilford Press: London, UK, 2007; pp. 224-239.

82. Ward, M.; Gruppen, L.; Regehr, G. Measuring self-assessment: Current state of art. Adv. Health Sci. Educ. 2002, 7, 63-80. [CrossRef] 